\title{
Analysis of the Growth of Anadara granosa (Bivalvia: Arcidae) in Natural, Artificially Seeded and Experimental Populations
}

\author{
M. J. Broom* \\ Department of Zoology, University of Malaya, Kuala Lumpur 22-11, Malaysia
}

\begin{abstract}
The growth of both natural and artificially seeded populations of Anadara granosa (L.) was monitored at 2 locations on the west coast of West Malaysia. Growth conforms to the von Bertalanffy model and the best estimates of the growth constant $(k)$ and asymptotic length $\left(L_{\infty}\right)$ are 1.01 $\mathrm{yr}^{-1}$ and $44.4 \mathrm{~mm}$ respectively for populations under optimum conditions. Initial results from natural populations indicated that density and exposure (height on the shore) are the major factors exerting an influence on growth rate. There was no evidence of any seasonal variation in growth but other factors such as extreme salinity fluctuations may be important in marginal populations. A series of field experiments confirmed the observations on natural populations that density and exposure do indeed have a marked effect upon growth. However, equal changes in exposure do not produce proportional changes in growth rate. It is suggested that the observed pattern may be part of a general negative sigmoidal relationship between growth and exposure. A relation which links growth (in the form of a variable asymptotic size) to population biomass (dry weight tissue per unit area) is developed as a first step toward accounting for the effects of changes in population biomass on predicted growth rates and yields.
\end{abstract}

\section{INTRODUCTION}

The arcid bivalve mollusc Anadara granosa (L.) (locally known as a cockle, although this term has no taxonomic significance) is an important natural marine product in Malaysia. In 1979 a total of 63,412 metric tons were landed, accounting for $11.1 \%$ of the total catch (by weight) of marine species. Only trash fish $(26.4 \%)$ and penaeid prawns $(12 \%)$ accounted for greater proportions of the catch (Government of Malaysia, 1980).

The bivalve is the subject of both a fishery (from natural populations) and extensive culture operations but despite the fact that it is such a valuable resource little work has been done to collect and standardise data on growth and mortality so that it might be utilised to predict yield under varying conditions. Pathansali and Soong (1958) and Pathansali (1963a, b, 1966)

- Present address: Welsh Water Authority, Tremains House, Coychurch Rd., Bridgend, CF31 2AR, United Kingdom provide some information on some aspects of the biology of this organism and of culture techniques but this is not sufficient for the purposes of efficient management. Yoo (1971) has provided information on the growth of a subspecies, Anadara granosa bisenensis Schrenck et Reinhart, from Korea, but this appears to be a slower-growing form (possibly due to the difference in latitude) and his data are not applicable in Malaysia.

As part of a programme to provide additional data for management purposes the growth of natural, artificially seeded and experimental populations was studied between 1977 and 1979 and this paper presents the results of those studies. The term 'natural population' refers to one which has become established as the result of a natural spatfall. The term 'artificially seeded population' means one placed by local culturists in an area where spatfall does not occur naturally, and the term 'experimental population' refers to one set up by the author as part of a field experiment. 


\section{METHODS}

\section{Natural and Artificially Seeded Populations}

Two natural populations and 3 artificially seeded populations were monitored. The natural populations were at Sungei Buloh $\left(3^{\circ} 15^{\prime} \mathrm{N}, 101^{\circ} 18^{\prime} \mathrm{E}\right)$ and Kuala Selangor $\left(3^{\circ} 20^{\circ} \mathrm{N}, 101^{\circ} 14^{\prime} \mathrm{E}\right)$ on the west coast of peninsular Malaysia. The position of the natural population at Kuala Selangor is illustrated in Fig. 1 and the position of that at Sungei Buloh is illustrated in Broom (in press). General site characteristics are also given in Broom (in press) but it should be noted that the natural population at Sungei Buloh was subjected to extreme tidal salinity changes from $28 \% \mathrm{~S}$ at high tide to as little as $5 \%$ S approaching low tide (at low tide the site is exposed), coupled with very high concentrations of suspended solids at periods of maximum flow.

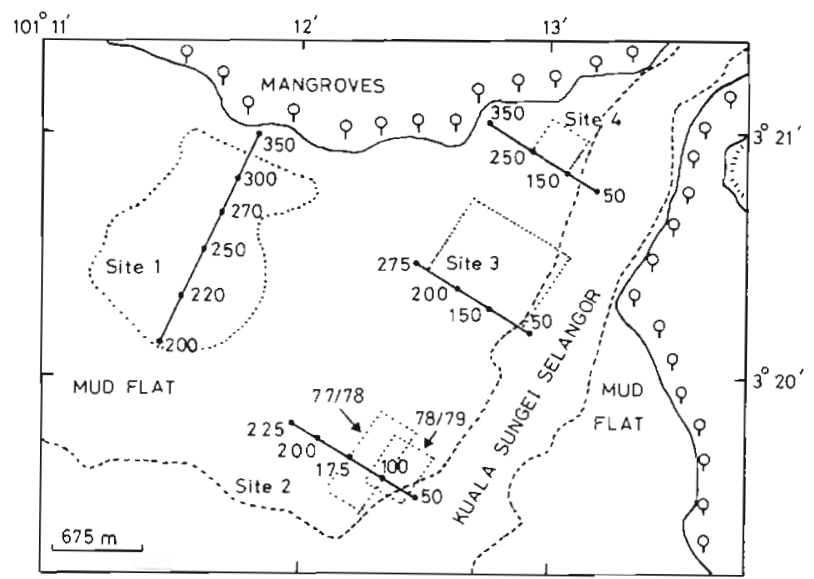

Fig. 1. Map showing the positions of study populations of Anadara granosa at Kuala Selangor. Dotted line: boundary of A. granosa populations. Broken line: edge of mudflat. Stilted circles: edge of mangrove swamp forest. Figures against the transect lines (solid circles) represent height above chart datum $(\mathrm{cm})$

The artificially seeded populations were all at Kuala Selangor. Their positions are shown in Fig. 1. They are labelled Sites 2 and 3 to distinguish them from the natural population (Site 1). Table 1 summarises the range of elevations occupied by the populations and the periods over which they were studied.

Between 10 and 20 samples were collected from each of the populations at 1 to 2 mo intervals by means of a hand-held dredge operated from a small dinghy. The dredge consisted of a wire basket-like structure affixed to a long wooden pole. It retained bivalves larger than $2 \mathrm{~mm}$ in their smallest dimension and sampled an area of $0.4 \mathrm{~m}^{2}$. The samples thus obtained also provided the population density estimates to which reference is made under 'Results' when appropriate. Specimens of Anadara granosa were subse-
Table 1. A summary of shore elevations occupied by the populations of Anadara granosa and periods during which they were sampled. $(C D=$ chart datum)

\begin{tabular}{|lrll|}
\hline \multicolumn{1}{c}{ Site } & \multicolumn{1}{c|}{$\begin{array}{c}\text { Elevation } \\
\text { (cm above CD })\end{array}$} & Period studied \\
\hline Sungei Buloh & $140-200$ & Jul 1977-Aug 1978 \\
Kuala Selangor Site 1 & $200-320$ & Aug 1978-Aug 1979 \\
Kuala Selangor Site 2 & $125-175$ & Aug 1977-Mar 1978 \\
Kuala Selangor Site 2 & $75-150$ & Jul 1978-Jul 1979 \\
Kuala Selangor Site 3 & $100-200$ & Aug 1977-May 1978 \\
\hline
\end{tabular}

quently sorted into different year classes. If possible a subsample of 100 individuals was taken from each year class on each sampling occasion and the specimens in the subsample were each weighed whole to the nearest $0.01 \mathrm{~g}$ after first blotting off excess water. However, older year classes occurred in very low densities and in these cases as many individuals as possible were weighed. At Kuala Selangor, Site 1, a careful note was kept of the area from which each sample was taken and of the characteristic fauna associated with it. In this manner it was possible to identify sub-populations within the site and growth rates of these could be examined separately.

On one occasion (14 February 1978) 45 samples were collected from the natural population at Sungei Buloh using a Birge-Ekmann box sampler of area $225 \mathrm{~cm}^{2}$. Specimens of Anadara granosa were separated from the sediment and those in each sample were counted and weighed as a group, allowing the generation of a density-mean weight matrix of data.

\section{Experimental Populations}

In May 1978 field experiments were set up at Kuala Selangor in the area marked as Site 4 (Fig. 1). Five plots measuring $10 \times 10 \mathrm{~m}$ each were marked off with long wooden stakes at an elevation of approximately $250 \mathrm{~cm}$ above chart datum (CD). They were sown as evenly as possible with young Anadara granosa at densities of $125,625,1250,1875$ and $2500 \mathrm{~m}^{-2}$. An additional 3 plots measuring $10 \times 10 \mathrm{~m}$ were each marked out at elevations of 150,200 and $250 \mathrm{~cm}$ above $\mathrm{CD}$ and sown with young $A$. granosa at a density of $100 \mathrm{~m}^{-2}$. Samples were collected from all plots at intervals dictated by weather conditions using the dredge mentioned above. At plots with initial densities of 625 $\mathrm{m}^{-2}$ or more only one sample was collected on each occasion and a sub-sample of 100 bivalves was removed and each weighed individually to the nearest $0.01 \mathrm{~g}$. At plots with densities of 100 or $125 \mathrm{ml}^{-2}$ samples were collected until at least 50 individuals had been obtained and all those collected were individually 
weighed. The samples were not replaced in the plots For the lowest density of $100 \mathrm{~m}^{-2}$ this represented a total removal during the sampling period, at ca 100 sample ${ }^{-1}$, of $7 \%$ of the number in the plot. This is assumed not to have had any measurable effect upon growth rates. Sampling continued until March 1979.

\section{Treatment of Data}

For comparative purpose, and to provide information that may subsequently used in computation of yield, it is necessary to fit the data to a model. The von Bertalanfy growth equation is used here as a model for growth of Anadara granosa for the following reasons and in the following manner.

The growth curves for both length and weight of many organisms are sigmoid (e. g. Crisp, 1971; Ricker, 1975) and molluscs in general are no exception (e. g. Yamaguchi, 1975; Ansell and Parulekar, 1978). Over a sufficiently long period the growth of Anadara granosa is also sigmoid. The original intention was to compute a growth constant for increases in weight, and an asymptotic weight, directly. However, in many instances - particularly at the artificially seeded sites monitoring could not be continued for a sufficiently long period (due to harvesting by local culturists) for the sigmoid form to manifest itself. Therefore all weight data were converted to mean length for purposes of analysis. This conferred the additional advantage that early data points (when rate of increase in weight was still increasing) which would otherwise have been omitted, could now be included in the analysis. Mean weights were converted to mean length using the following expressions which are based upon 150 total wet weights (to the nearest $0.01 \mathrm{~g}$ ) and lengths (to the nearest $0.1 \mathrm{~mm}$ ) in each case.

Kuala Selangor: $\quad L=1.490 \mathrm{~W}^{0.313} r^{2}=0.931$

Sungei Buloh: $\quad L=1.585 \mathrm{~W}^{0.289} r^{2}=0.973$

where $L=$ length $(\mathrm{cm}) ; W=$ total wet weight $(\mathrm{g})$; $r^{2}=$ coefficient of determination. The logarithmic forms of these expressions, including standard errors in parentheses, are

Kuala Selangor:

$\log L=0.3131( \pm 0.0070) \log W+0.1731( \pm 0.0058)$

Sungei Buloh:

$\log L=0.2885( \pm 0.0041) \log W \pm 0.0024)$

(The converse expressions from Broom (1982) calculated with length as the independent variable, are:
K. Selangor:
$W=0.245 \mathrm{~L}^{3.295} \quad r^{2}=0.993$
S. Buloh:

The higher values of the coefficient of determination, $r^{2}$, show that more of the variation in $W$ is explained by variation in $L$ than vice versa and in retrospect it would have been preferable to measure length directly. But the differences in $r^{2}$ are not large so that the additional error introduced by taking weights is small.)

Measurements of the growth in length of the 1979 settlement of Anadara granosa at Site 1, Kuala Selangor indicate that the first inflexion point occurs at a length of 4-5 $\mathrm{mm}$ (Broom, in press). It is therefore assumed that for all sizes greater than $5 \mathrm{~mm}$ the length increment per unit time of $A$. granosa, over short time intervals, can be adequately described by the derivative of the von Bertalanffy growth equation viz:

$$
\mathrm{dl} / \mathrm{dt}=\mathrm{k}\left(\mathrm{L}_{\infty}-\mathrm{l}\right)
$$

where $\mathrm{dl} / \mathrm{dt}$ is the increment per unit time between successive sampling dates $\left(\mathrm{mm} \mathrm{yr}^{-1}\right), 1$ is the mean length ( $\mathrm{mm}$ ) for the same time interval, $k$ is a constant (the growth constant) and $L_{\infty}$ is also a constant (the asymptotic length). On the basis of this assumption the growth data for natural and artificially seeded populations have been fitted to Equation 1 by least squares regression.

\section{Benthic Layer Chlorophyll a Measurements}

One hypothesis erected to account for some of the results described below is that a dense population of Anadara granosa might significantly reduce the concentration of food available to it in the near-bottom benthic layer. To test whether or not this might be true an attempt was made to measure the standing crop of benthic microalgae immediately above the sediment over (1) a dense bed of $\boldsymbol{A}$. granosa and (2) an area of virgin mud. The dense bed of $A$. granosa (ca. $1000 \mathrm{~m}^{-2}$ ) was a 'nursery' area established by local culturists between Sites 3 and 4 . Adjacent to this and immediately upstream from it was an area of mudflat which had not been utilised for culture for a period of 1 yг previously. On 22 January 197910 samples of water were collected from within $5 \mathrm{~cm}$ of the surface in each of these areas. Collection was carried out using 'snorkelling' equipment, each bottle being carried down to the bottom and opened in an undisturbed area. The samples were filtered through a GF/C glass fibre filter paper and the residue analysed for chlorophyll a (corrected for contribution by phaeopigments) and suspended solids following procedures described by Strickland and Parsons (1968). Acetone was used as the solvent and concentrations of chlorophyll a were calculated using the monochromatic expression given by Strickland and Parsons (1968, p. 194). 


\section{RESULTS}

The growth in weight of the 1977 and 1978 year classes of Anadara granosa at Sungei Buloh is shown in Fig. 2. The curves have been fitted by eye. For the 1977 year class 2 curves are presented, 1 passing through the majority of points and 1 passing through 4 depressed points. The depressed points fit well into a curve of their own but do not fit the general curve. Temporal variations in external factors such as food supply, temperature and salinity in this area were not sufficient to explain such growth variations (see Broom, in press). The depressed points did not correspond with known spawning times nor was there any evidence of sudden, size-selective mortality.

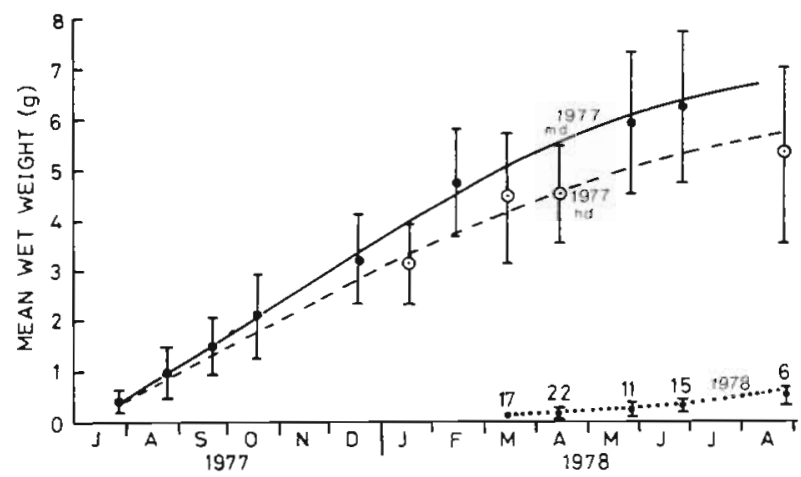

Fig. 2. Anadara granosa. Variation with time of mean wet weight of a population at Sungei Buloh. 1977 md: 1977 year class, moderate density; 1977 hd: 1977 year class, high density; 1978: 1978 year class. Mean and one standard deviation are presented. Sample size 100, unless otherwise indicated by figures above sample points

Table 2. Anadara granosa. Concentrations of chlorophyll a (chl. ' $a$ ' $\mathrm{mg} \mathrm{m}^{-3}$ ), and suspended solids (s. s., $\mathrm{g} \mathrm{m}^{-3}$ ) in nearbottom water above a dense population and above an adjacent, unpopulated mudflat. $\bar{x}=$ mean value, $s=$ standard deviation, $\mathrm{F}=$ variance ratio, $\mathrm{n}=10$

\begin{tabular}{|c|c|c|c|c|c|}
\hline \multirow[t]{2}{*}{ Parameter } & \multicolumn{2}{|c|}{$\begin{array}{c}\text { Dense } \\
\text { population }\end{array}$} & \multicolumn{2}{|c|}{$\begin{array}{c}\text { Unpopulated } \\
\text { area }\end{array}$} & \multirow[t]{2}{*}{$\mathrm{F}$} \\
\hline & $\bar{x}$ & $s$ & $\overrightarrow{\mathrm{x}}$ & s & \\
\hline Chl. 'a' $\left(\mathrm{mg} \mathrm{m}^{-3}\right)$ & 7.74 & 2.16 & 17.4 & 2.90 & $70.5 \cdots$ \\
\hline s.s. $\left(\mathrm{g} \mathrm{m}^{-3}\right)$ & 138 & 47 & 87 & 32 & $8.1^{\circ}$ \\
\hline$\mu \mathrm{g}$ chl. 'a (g. s.s.) $)^{-?}$ & 62 & 24 & 225 & 77 & $36.7^{\cdots}$ \\
\hline$\cdot 0.05>p>0.01$ & & & & & \\
\hline$\cdots p<0.001$ & & & & & \\
\hline
\end{tabular}

However, the depressed points of the curve did correspond with occasions when particularly high estimates of density were obtained (Fig. 3). The results of the estimates of chlorophyll a concentrations above populated and unpopulated areas of mudflat, pre- sented in Table 2, show that a dense population of Anadara granosa may reduce such concentrations. If chlorophyll a is taken as a useful proxy measure of nutritive material available to the bivalve then the overall effect might be a reduction in growth rate, especially as the concentration of suspended solids above the $A$. granosa population was elevated (possibly due to production of faecal material with a low bulk density), thus effectively diluting the available chlorophyll a still further. Bayne and Worral (1980) have shown that for Mytilus edulis the ratio between total seston ( = total particulate matter in suspension) and particulate organic matter has a crucial influence upon growth rates because the diluting effect of inorganic matter reduces assimilation efficiency. This could be particularly important in a highly turbid area such as a mudflat. The depressed points occurred in the latter half of the year when biomass increases would be expected to have their maximum effect in dense patches; it is therefore concluded that they result from the collection of excess samples from areas of high density and depressed growth. This view is supported by evidence from the density-mean weight data matrix (Fig. 4). This shows a trend towards a progres-

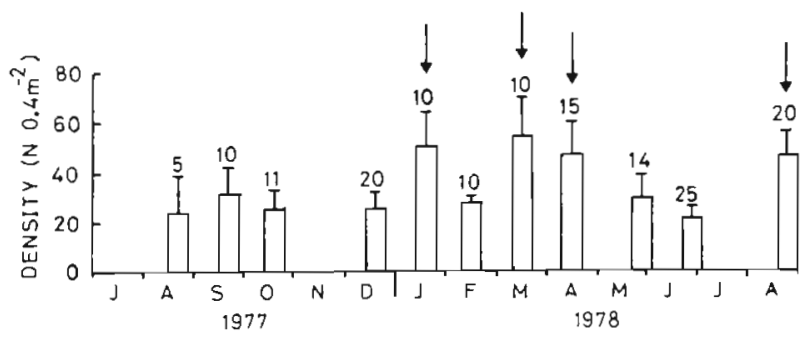

Fig. 3. Anadara granosa. Variation with time of population density at Sungei Buloh. Figures above sample points represent number of samples taken. Mean and one standard error are presented. Arrowed points correspond to low mean weight estimates

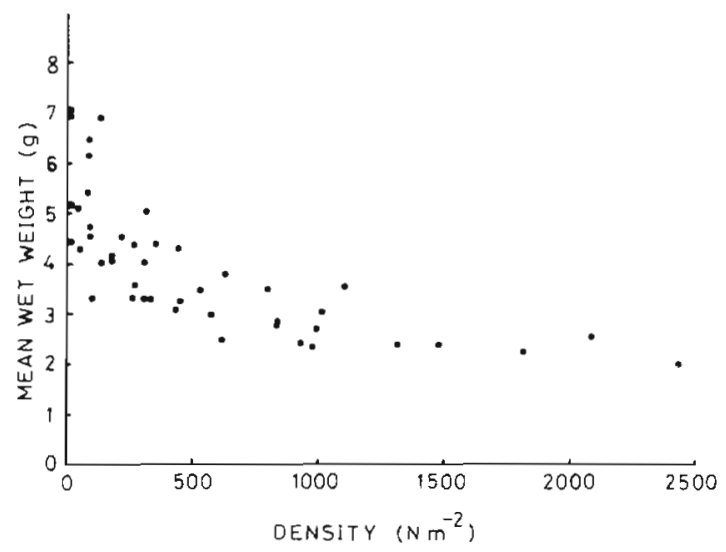

Fig. 4. Anadara granosa. Plot of mean wet weight against population density for individuals collected from Sungei Buloh on 14 February 1978 
sively smaller mean weight at progressively greater densities. The exact form such a relationship might take is uncertain but a plot of log density against mean wet weight yields a significant negative correlation $(r=-0.8157 ; p \ll 0.01 ;$ d.f. $=44)$.

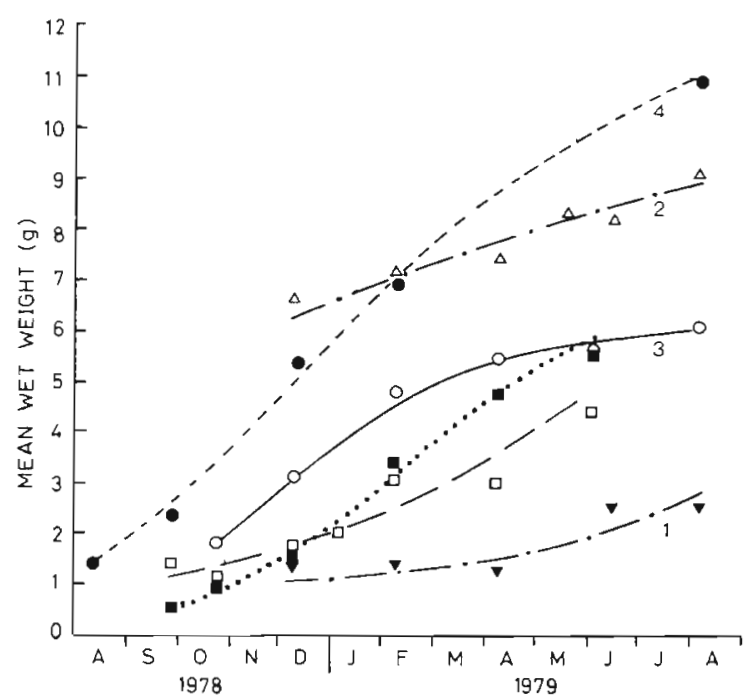

Fig. 5. Anadara granosa. Variation with time of mean wet weight of sub-populations at Kuala Selangor, Site 1. Maximum density $<500 \mathrm{~m}^{-2}: 1=320 \mathrm{~cm}$ above $\mathrm{CD}, 1978$ year class; $2=320 \mathrm{~cm}$ above $\mathrm{CD}, 1977$ year class; $3=270 \mathrm{~cm}$ above $\mathrm{CD} ; 4=200 \mathrm{~cm}$ above $\mathrm{CD}$ : Maximum density $>1000$ $\mathrm{m}^{-2}$ : $\square 220$ to $250 \mathrm{~cm}$ above CD. Maximum density 500 to 1000 $\mathrm{m}^{-2}$ incl. Pelecyora trigona: $260 \mathrm{~cm}$ above $\mathrm{CD}$

At Kuala Selangor, Site 1, distinctions were drawn between sub-populations of Anadara granosa of moderate density at 3 different elevations (200, 270 and $320 \mathrm{~cm}$ above $\mathrm{CD}$ ), a denser sub-population where large quantities of dead shell were found, and an area containing a potential competitor, the bivalve Pelecyora trigona (Reeve) (at $260 \mathrm{~cm}$ above CD).
The growth in mean weight of each sub-population is illustrated in Fig. 5 and the full data are summarised in Table 3. Between June and August large-scale harvesting was carried out between elevations of 200 and $270 \mathrm{~cm}$ above $\mathrm{CD}$ and as a consequence the August point for the $200 \mathrm{~cm}$ sub-population is based on the weights of only 13 individuals. However, by June virtually all the members of the population were of a size that would be retained by commercial dredges and the 13 specimens collected in August are not thought to represent a size-selected population. On the other hand the frequency distributions of samples taken from $270 \mathrm{~cm}$ above CD on 4 June and 6 August 1979 indicated that in these cases some degree of size selection had taken place and the final 2 points are undoubtedly depressed somewhat.

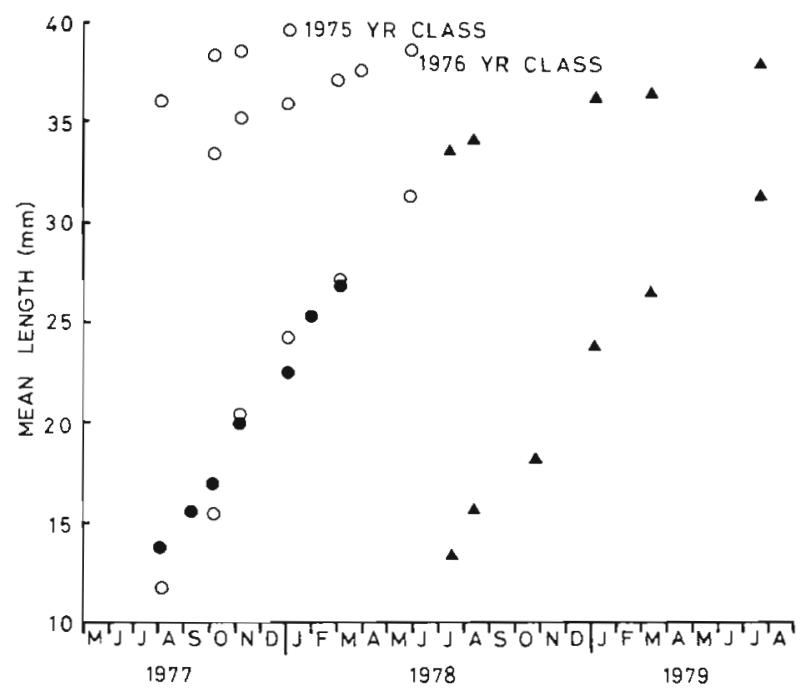

Fig. 6. Anadara granosa. Variation with time of mean length of individuals from artificially seeded sites at Kuala Selangor

- Site 2,1977/78; $\triangle$ Site 2, 1978/79; O Site 3, 1977/78

Table 3. Anadara granosa. Changes in mean wet weight of sub-populations from Kuala Selangor, Site 1

\begin{tabular}{|c|c|c|c|c|c|c|c|c|c|c|c|c|c|c|c|c|c|c|}
\hline \multirow[b]{2}{*}{ Date } & \multicolumn{3}{|c|}{$\begin{array}{l}200 \mathrm{~cm} \text { above } \mathrm{CD} \\
\text { Density }<500 \mathrm{~m}^{-2}\end{array}$} & \multicolumn{3}{|c|}{$\begin{array}{l}270 \mathrm{~cm} \text { above } \mathrm{CD} \\
\text { Density }<500 \mathrm{~m}^{-2}\end{array}$} & \multicolumn{3}{|c|}{$\begin{array}{c}320 \mathrm{~cm} \text { above CD } \\
1978 \text { yr class } \\
\text { Density }<500 \mathrm{~m}^{-2}\end{array}$} & \multicolumn{3}{|c|}{$\begin{array}{c}320 \mathrm{~cm} \text { above } \mathrm{CD} \\
1977 \text { y } \text { class } \\
\text { Density }<500 \mathrm{~m}^{-2}\end{array}$} & \multicolumn{3}{|c|}{$\begin{array}{c}220-250 \mathrm{~cm} \\
\text { above CD } \\
\text { Density }>1000 \mathrm{~m}^{-2}\end{array}$} & \multicolumn{3}{|c|}{$\begin{array}{c}260 \mathrm{~cm} \text { above CD } \\
+P \text { trigona } \\
500-1000 \mathrm{~m}^{-2}\end{array}$} \\
\hline & W & $s$ & $\mathrm{n}$ & W & $\mathrm{s}$ & $\mathrm{n}$ & $W$ & $\mathrm{~s}$ & $\mathrm{n}$ & $W$ & $\mathrm{~s}$ & $\mathrm{n}$ & $\mathrm{W}$ & $\mathrm{s}$ & $\mathrm{n}$ & $W$ & $s$ & $\mathrm{n}$ \\
\hline $11 / 8 / 78$ & 1.40 & 0.23 & 40 & & & & & & & & & & & & & & & \\
\hline $29 / 9 / 78$ & 2.32 & 0.65 & 100 & & & & & & & & & & 1.41 & 0.59 & 100 & 0.70 & 0.24 & 100 \\
\hline $25 / 10 / 78$ & & & & 1.75 & 0.63 & 100 & & & & & & & 1.16 & 0.46 & 100 & 1.05 & 0.39 & 100 \\
\hline $10 / 12 / 78$ & 5.28 & 1.11 & 60 & 3.10 & 0.68 & 100 & 1.41 & 0.53 & 100 & 6.58 & 1.30 & 21 & 1.81 & 0.25 & 40 & 1.67 & 0.65 & 100 \\
\hline $8 / 2 / 79$ & 6.92 & 1.25 & 80 & 4.80 & 1.02 & 100 & 1.43 & 0.65 & 95 & 7.10 & 1.65 & 40 & 3.05 & 0.78 & 100 & 3.48 & 0.83 & 100 \\
\hline $8 / 4 / 79$ & & & & 5.45 & 1.43 & 100 & 1.33 & 0.62 & 100 & 7.42 & 1.30 & 16 & 3.02 & 0.96 & 100 & 4.83 & 1.18 & 100 \\
\hline $20 / 5 / 79$ & & & & & & & 2.23 & 0.82 & 100 & 8.30 & 1.40 & 15 & & & & & & \\
\hline $4 / 6 / 79$ & & & & 5.58 & 1.40 & 100 & & & & & & & 4.43 & 1.14 & 100 & 5.57 & 1.35 & 100 \\
\hline $17 / 6 / 79$ & & & & & & & 2.48 & 0.83 & 100 & 8.14 & 0.83 & 32 & & & & & & \\
\hline $6 / 8 / 79$ & 10.93 & 1.86 & 13 & 6.08 & 1.53 & 60 & 2.47 & 1.12 & 56 & 9.38 & 2.31 & 25 & & & & & & \\
\hline
\end{tabular}


Table 4. Anadara granosa. Changes in mean wet weight of artificially seeded populations at Kuala Selangor, Sites 2 and 3

\begin{tabular}{|c|c|c|c|c|c|c|c|c|c|c|c|c|c|c|c|c|c|}
\hline \multicolumn{9}{|c|}{ Site 2} & \multirow{2}{*}{\multicolumn{9}{|c|}{$\begin{array}{l}\text { Site } 3 \\
1977 / 78\end{array}$}} \\
\hline \multicolumn{3}{|c|}{$1977 / 78$} & \multicolumn{6}{|c|}{$1978 / 79$} & & & & & & & & & \\
\hline \multirow[t]{2}{*}{ Date } & \multicolumn{2}{|c|}{$\begin{array}{c}1977 \\
y t \text { class }\end{array}$} & \multirow[t]{2}{*}{ Date } & \multicolumn{3}{|c|}{$\begin{array}{c}1977 \\
y x \text { class }\end{array}$} & \multicolumn{2}{|c|}{$\begin{array}{c}1978 \\
y r \text { class }\end{array}$} & \multirow[t]{2}{*}{ Date } & \multicolumn{3}{|c|}{$\begin{array}{c}1975 \\
\text { yr class }\end{array}$} & \multicolumn{3}{|c|}{$\begin{array}{c}1976 \\
\text { yr class }\end{array}$} & \multicolumn{2}{|c|}{$\begin{array}{c}1977 \\
\text { yr class }\end{array}$} \\
\hline & $\dot{w}$ & $s$ & & $W$ & $s$ & $\mathrm{n}$ & W & $\mathrm{s}$ & & W & $s$ & n & W & $s$ & $\mathrm{n}$ & $w$ & $\mathrm{~s}$ \\
\hline $4 / 8 / 77$ & 0.83 & 0.34 & $13 / 7 / 78$ & 13.27 & 1.94 & 5 & 0.69 & 0.28 & $4 / 8 / 77$ & 18.15 & 0.95 & 8 & & & & 0.48 & 0.34 \\
\hline $7 / 9 / 77$ & 1.12 & 0.63 & $11 / 8 / 78$ & 13.89 & 4.09 & 7 & 1.17 & 0.40 & $5 / 10 / 77$ & 20.37 & 2.39 & 6 & 13.15 & 2.80 & 50 & 1.15 & 0.43 \\
\hline $5 / 10 / 77$ & 1.63 & 0.41 & $25 / 10 / 78$ & & & & 1.86 & 0.77 & $5 / 11 / 77$ & 20.81 & 2.09 & 10 & 15.41 & 2.89 & 30 & 2.80 & 1.31 \\
\hline $5 / 11 / 77$ & 2.51 & 0.73 & $5 / 1 / 79$ & 16.53 & 2.95 & 12 & 4.41 & 1.09 & $3 / 1 / 78$ & 22.49 & 2.10 & 6 & 16.48 & 1.38 & 16 & 4.70 & 1.38 \\
\hline $3 / 1 / 77$ & 3.86 & 1.43 & $10 / 3 / 79$ & 16.92 & 4.78 & 13 & 6.19 & 1.47 & $3 / 3 / 78$ & & & & 18.51 & 1.52 & 20 & 6.78 & 1.52 \\
\hline $1 / 2 / 78$ & 5.35 & 1.01 & $25 / 5 / 79$ & & & & 7.47 & 1.87 & $30 / 3 / 78$ & & & & 19.23 & 3.44 & 23 & 6.87 & 1.59 \\
\hline $3 / 3 / 78$ & 6.48 & 1.73 & $21 / 7 / 79$ & 19.54 & 2.72 & 5 & 10.64 & 2.13 & $28 / 5 / 78$ & & & & 20.87 & 3.70 & 21 & 10.69 & 2.27 \\
\hline
\end{tabular}

Fig. 5 shows that in the area encompassed by Site 1 there may be considerable variation in growth rates exhibited by different sub-populations. In particular there were marked differences between sub-populations at different densities but broadly comparable elevations. Sigmoid curves were exhibited by those sub-populations that occurred at moderate elevations and densities. In those populations which were subject to more extreme conditions such as high density and/or high elevation the sigmoid form is not discernible, possibly because growth was very slow and sampling error too large to allow small changes to be accurately detected.

Data on changes in mean weight of different year classes in the artificially seeded populations at Sites 2 and 3 are presented in Table 4 . The mean weights given in this table have been converted to mean length and are presented graphically in Fig. 6. At Site 2,
$1977 / 78$, the whole population was harvested rapidly after March 1978. At Site 2, 1978/79, harvesting took place from April 1979 onwards. In the early stages this was size-selective and accounts for the apparent decrease in growth rate between March and May. However, by the end of May the majority of the population had reached a catchable size so that the increase in weight between May and July is probably a reasonable estimate of growth.

Taking the results as a whole it is clear that there is a progressive decrease in growth rate as size increases and this approximates to a von Bertalanffy model.

After converting all weight data to mean length the appropriate growth constants have been calculated from the derived regression equations using Equation 1 as a model. The information thus obtained is presented in Table 5. Estimates of growth increments in the artificially seeded populations thought to have

Table 5. Anadara granosa. Growth constant $(k)$ and asymptotic size $\left(L_{\infty}\right)$ of several populations obtained when data on growth in mean length are fitted to Equation 1

\begin{tabular}{|c|c|c|c|c|c|c|}
\hline $\begin{array}{c}\text { Population or collection } \\
\text { of data points }\end{array}$ & $\begin{array}{c}k \\
\left(y^{-1}\right)\end{array}$ & $\mathrm{SE}(\mathrm{k})$ & $\underset{(\mathrm{mm})}{L}$ & $r^{2}$ & $F$ & d.f. \\
\hline K.S. Site 1, $200 \mathrm{~cm}$ & 1.35 & 0.840 & 37.0 & 0.564 & 2.04 & 1. 2 \\
\hline K.S. Site $1,270 \mathrm{~cm}$ & 4.17 & 0.579 & 26.5 & 0.946 & $52.07^{\cdots}$ & 1. 3 \\
\hline $\begin{array}{l}\text { K.S. Site 1, } 260 \mathrm{~cm} \\
+ \text { Pelecyora trigona }\end{array}$ & 1.37 & 0.704 & 33.4 & 0.558 & 3.79 & 1,3 \\
\hline K.S. Site $2,77 / 78$ & 0.28 & 0.745 & 60.8 & 0.034 & 0.14 & 1,4 \\
\hline K.S. Site $2,78 / 79$ & 0.99 & 0.287 & 41.1 & 0.630 & $11.93^{\circ}$ & 1,7 \\
\hline K.S. Site $2,77 / 78 / 79$ & 0.91 & 0.249 & 43.8 & 0.505 & $13.28^{*}$ & 1,13 \\
\hline K.S. Site $3,77 / 78$ & 1.42 & 0.154 & 42.8 & 0.554 & $13.14^{\cdots}$ & 1.11 \\
\hline K.S. Sites 2 \& 3, all data & 1.01 & 0.220 & 44.4 & 0.451 & $21.32 \cdots$ & 1,26 \\
\hline $\begin{array}{l}\text { S. Buloh } \\
\text { moderate density }\end{array}$ & 2.99 & 0.535 & 27.6 & 0.862 & $31.21^{\cdots}$ & 1,5 \\
\hline S. Buloh, high density & 2.15 & 0.808 & 27.1 & 0.780 & 7.10 & 1. 2 \\
\hline
\end{tabular}


been affected by size-selective mortality, were omitted from the data used to produce the regressions. The asymptotic size predicted from the largest collection of data points (all data for Sites 2 and 3 ) is in good agreement with the size of the largest individuals found in the field which seldom exceeded $45 \mathrm{~mm}$ in length.

The results reflect the conclusions already drawn from Figs. 2, 4 and 5 in that the $L_{\infty}$ values are reduced and $k$ values increased at high elevations and/or high densities. Not all the data yield significant regressions and where non-significance occurs little confidence can be placed in the predictions for $L_{\infty}$ and $k$. Nevertheless, non-significance is usually the result of regressions based on too few data points rather than on extremely variable data.

The data relating to increase in weight of Anadara granosa in the field experiments are presented in Tables 6 and 7 , and the corresponding mean length values are plotted in Fig. 7. A ' $t$ ' test of the hypothesis that there is no difference between the mean weights of populations in adjacent experimental plots on the final sampling date indicates that there were, in fact, significant differences between all pairs tested except for the groups initially sown at 2500 and $1875 \mathrm{~m}^{-2}$, although even for this pair the probability that the samples were not drawn from substantially different populations is not greater than $10 \%$. The relevant statistical information concerning this test is presented in Table 8.

A plot of the weight vs. time data presented in Tables 6 and 7 actually gives the impression that the growth curves are continually diverging. However, when mean weights are converted to mean lengths this impression disappears and it would be difficult to ascribe a form other than a straight line to the growth in length of most of the experimental populations. It is assumed, for the purposes of an analysis presented below, that the apparent straight-line growth is a small section of a von Bertalanffy-type growth curve.

\section{DISCUSSION}

The results of the study of natural populations indicate that density and exposure are the major factors controlling growth of Anadara granosa. Field experiments confirm that both density and exposure can affect growth but it is difficult to decide which is more important. Work on other intertidal molluscs seem to point to density as the more important factor. For example, Sutherland (1970) found growth in popula-

Table 6. Anadara granosa. Changes in mean wet weight of individuals placed in experimental plots at Kuala Selangor at different initial densities

\begin{tabular}{|c|c|c|c|c|c|c|c|c|c|c|c|c|c|c|c|}
\hline \multirow[b]{2}{*}{ Date } & \multicolumn{3}{|c|}{$\begin{array}{l}\text { Initial density } \\
\qquad 2500 \mathrm{~m}^{-2}\end{array}$} & \multicolumn{3}{|c|}{$\begin{array}{l}\text { Initial density } \\
1875 \mathrm{~m}^{-2}\end{array}$} & \multicolumn{3}{|c|}{$\begin{array}{l}\text { Initial density } \\
\quad 1250 \mathrm{~m}^{-2}\end{array}$} & \multicolumn{3}{|c|}{$\begin{array}{l}\text { Initial density } \\
\quad 625 \mathrm{~m}^{-2}\end{array}$} & \multicolumn{3}{|c|}{$\begin{array}{l}\text { Initial density } \\
\qquad 125 \mathrm{~m}^{-2}\end{array}$} \\
\hline & W & $\mathrm{s}$ & $\mathrm{n}$ & W & $\mathrm{s}$ & $\mathrm{n}$ & W & $\mathrm{s}$ & $\mathrm{n}$ & $W$ & $s$ & $\mathrm{n}$ & $W$ & $\mathrm{~s}$ & $\mathrm{n}$ \\
\hline $15 / 5 / 78$ & 0.23 & 0.11 & 200 & 0.23 & 0.11 & 200 & 0.23 & 0.11 & 200 & 0.23 & 0.11 & 200 & 0.23 & 0.11 & 200 \\
\hline $27 / 8 / 78$ & 0.38 & 0.21 & 100 & 0.47 & 0.37 & 100 & 0.76 & 0.36 & 100 & 0.79 & 0.36 & 100 & 0.98 & 0,47 & 50 \\
\hline $10 / 10 / 78$ & 0.49 & 0.36 & 100 & 0.63 & 0.34 & 100 & 0.84 & 0.32 & 100 & 1.09 & 0.44 & 100 & 1.38 & 0.54 & 50 \\
\hline $23 / 11 / 78$ & 0.59 & 0.34 & 100 & 0.75 & 0.31 & 100 & 0.92 & 0.40 & 100 & 1.23 & 0.53 & 100 & 1.56 & 0.55 & 50 \\
\hline $22 / 1 / 79$ & 0.94 & 0.57 & 100 & 1.23 & 0.53 & 100 & 1.34 & 0.53 & 100 & 1.66 & 0.55 & 100 & 2.35 & 0.70 & 50 \\
\hline $7 / 3 / 79$ & 1.36 & 0.64 & 100 & 1.47 & 0.63 & 100 & 1.90 & 0.75 & 100 & 2.46 & 1.14 & 100 & 3.45 & 0.90 & 50 \\
\hline
\end{tabular}

Table 7. Anadara granosa. Changes in mean wet weight of individuals placed in experimental plots at Kuala Selangor at different heights above chart datum (CD)

\begin{tabular}{|c|c|c|c|c|c|c|c|c|c|}
\hline \multirow[b]{2}{*}{ Date } & \multicolumn{3}{|c|}{$250 \mathrm{~cm}$ above $\mathrm{CD}$} & \multicolumn{3}{|c|}{$200 \mathrm{~cm}$ above $C D$} & \multicolumn{3}{|c|}{$150 \mathrm{~cm}$ above $\mathrm{CD}$} \\
\hline & W & s & n & W & $\mathrm{s}$ & $\mathrm{n}$ & W & $s$ & $\mathrm{n}$ \\
\hline $15 / 5 / 78$ & 0.23 & 0.11 & 200 & 0.23 & 0.11 & 200 & 0.23 & 0.11 & 200 \\
\hline $26 / 7 / 78$ & 0.49 & 0.24 & 100 & 0.62 & 0.37 & 100 & 0.69 & 0.28 & 100 \\
\hline $10 / 10 / 78$ & 1.06 & 0.51 & 100 & 1.27 & 0.54 & 80 & 1.86 & 0.88 & 100 \\
\hline $23 / 11 / 78$ & 1.36 & 0.59 & 100 & 1.75 & 0.75 & 100 & 3.20 & 0.80 & 64 \\
\hline $22 / 1 / 79$ & 2.38 & 0.67 & 80 & 2.52 & 0.65 & 100 & 4.52 & 1.52 & 66 \\
\hline $7 / 3 / 79$ & 3.45 & 1.04 & 100 & 3.68 & 0.85 & 100 & 5.71 & 1.63 & 64 \\
\hline
\end{tabular}



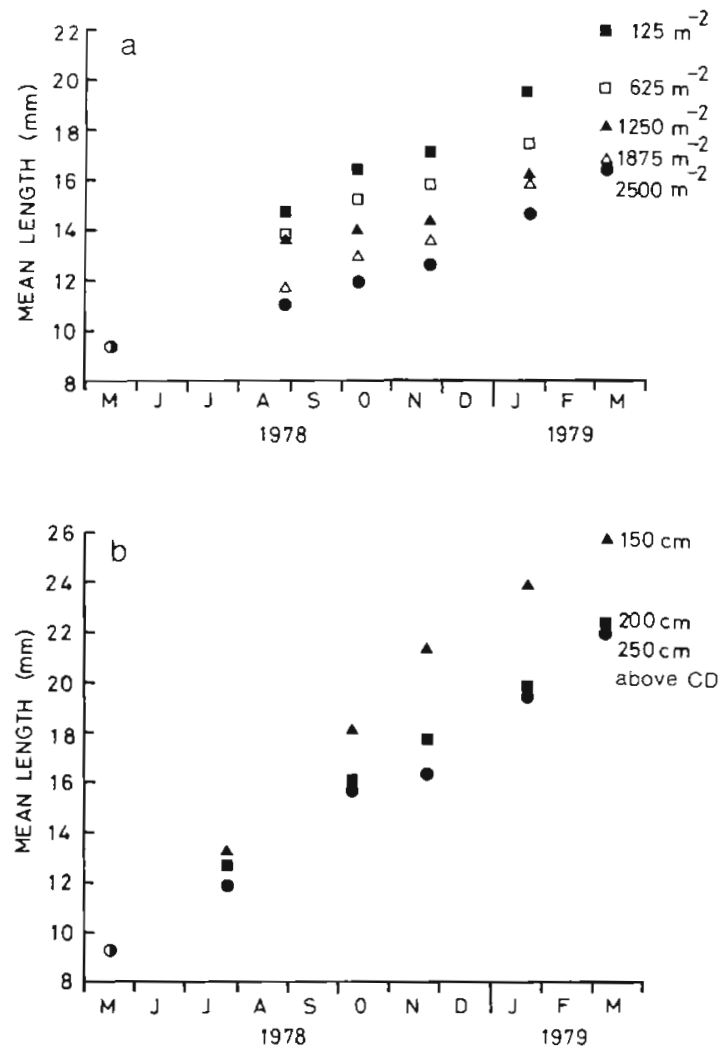

Fig. 7. Anadara granosa. Variation with time of the mean length of experimental populations at Site 4, Kuala Selangor at different initial densities (a) and different elevations on the shore (b). is initial size

Table 8. Anadara granosa. Results of a ' $t$ ' test on the final mean weights of adjacent populations in experimental plots

\begin{tabular}{|lrrr|}
\hline \multicolumn{1}{|c}{ Pair tested } & $\mathrm{t}$ & d.f. & Significance \\
\hline Density: & & & \\
$2500 \mathrm{~m}^{-2}$ vs. $1875 \mathrm{~m}^{-2}$ & 1.73 & 198 & $0.1>\mathrm{p}>0.05$ \\
$1875 \mathrm{~m}^{-2}$ vs. $1250 \mathrm{~m}^{-2}$ & 6.21 & 198 & $\mathrm{p}<0.001$ \\
$1250 \mathrm{~m}^{-2}$ vs. $625 \mathrm{~m}^{-2}$ & 5.80 & 198 & $\mathrm{p}<0.001$ \\
$625 \mathrm{~m}^{-2}$ vs. $125 \mathrm{~m}^{-2}$ & 5.36 & 148 & $\mathrm{p}<0.001$ \\
& & & \\
Exposure: & 2.42 & 198 & $0.02>\mathrm{p}>0.01$ \\
$250 \mathrm{~cm}$ vs. $200 \mathrm{~cm}$ & 10.43 & 162 & $\mathrm{p}<0.001$ \\
$200 \mathrm{~cm}$ vs. $150 \mathrm{~cm}$ & & & \\
& & \\
t Student's 't'; d.f. degrees of freedom & \\
\end{tabular}

tions of Acmaea scabra in California to be faster at higher shore levels than at lower levels, and Green and Hobson (1970) observed a similar pattern in the growth of the infaunal bivalve Gemma gemma. In both cases higher densities at lower elevations inhibited growth. There are other factors which may be of importance. For example, Green (1973) found that in Arctic populations of Macoma balthica growth was faster at higher than at lower elevations but attributed this to the greater mean temperatures at the higher elevations. Beukema et al. (1977) reported variations in growth rate of $M$. balthica in the intertidal areas of the Dutch Waddensea to be related both to time available for feeding and to food supply (in the form of standing crop and production of benthic microalgae) so that growth was often faster at moderately high elevations than at low elevations.

That factors other than density and elevation may affect the growth of Anadara granosa is shown by the poor average growth rate of the moderately dense portion of the population at Sungei Buloh, despite its relatively low elevation. This may have been due to the extreme tidal fluctuations in salinity and turbidity at this site which might be expected to reduce feeding time. These factors may also account for the poor condition of the population at this site. In most individuals the red-brown periostracum which gives the shell its usual appearance was not present and specimens had a dirty white colour. The shell was frequently very thin, especially near the umbones, and live individuals were often found with parts of the fragile shell completely worn away leaving a gaping hole exposing the flesh.

Very slow growth was also observed in the subpopulation at Kuala Selangor, Site 1, $320 \mathrm{~cm}$ above chart datum. This elevation is close to the mean high water of neap tides (ca. $3.8 \mathrm{~m}$ ) and during neap tides under calm, sunny conditions the temperature of both water and sediment at the water's edge may rise as high as $40^{\circ} \mathrm{C}$ (Broom, 1980). Furthermore the shallow water is a permanently turbid environment. These 2 factors together may result in an elevated metabolic rate coupled with restricted filtration time which might combine to produce poor growth. This effect has been noted by Barnett (Scottish Marine Biological Association, 1973, cited by Moore, 1977, p. 287) who observed that the body weight of a standard size Tellina tenuis was reduced in an area receiving warm water and subjected to prolonged intervals of high turbidity. Nevertheless, whether temperature and turbidity actually affect the growth of Anadara granosa is not known.

From the experiments equivalent changes in exposure do not appear to produce proportional changes in growth rate, the final mean weights at 200 and $250 \mathrm{~cm}$ above chart datum being only slightly different. Some reasons for this lack of proportional difference in growth may be deduced: Anadara granosa has been observed to continue to feed from the surface film of water on the mudflalts even when the tide is out (Broom, in press) and this will tend to remove a major restriction on growth at higher shore levels, namely reduced feeding time during shorter periods of tidal cover. Other possibilities are that there may be com- 
pensatory feeding activity during periods of tidal cover or some degree of metabolic adaptation. Winter (1978) found that Mytilus edulis populations subjected to maximum exposure may feed faster during periods of cover than populations lower down the shore. Calow (1977) presented evidence that invertebrates exhibit a whole range of metabolic adaptations in response to a change in the quality and quantity of food available. These adaptations include depression of the metabolic maintenance requirement and an increase in the time food is retained in the gut, thereby allowing more effective assimilation.

Although demonstrable differences in growth rate in relation to density and exposure do occur, for comparative purposes the data need to be standardised in some way. Ideally one would wish to calculate both the growth constant $(k)$ and the asymptotic length $\left(L_{\infty}\right)$ but the growth data for most of the experimental plots are too variable to allow a fit to Equation 1 to be attempted. Therefore, because the data do not allow a graphical interpretation, the only alternative is to fix one constant at a selected value and compute the other using the equation

$L_{\infty}=\left(1_{t+T}-1_{t} e^{-k T}\right) /\left(1-e^{-k T}\right) \quad$ (2) (Gulland, 1969)

where $I_{t+T}=$ length after a time interval $T$ following the previous measurement $(1)$.

Gulland (1972) suggested that the easiest way to take account of the effects of density on growth is to allow the asymptotic size to vary as a function of population biomass, and for this reason I have chosen to hold $k$ constant and calculate $L_{\infty}$. The underlying assumption is that increases in density limit available food per individual and that this results in a decrease in asymptotic size. A similar effect can be postulated for exposure. Organisms higher up the shore would have less time to feed and hence would suffer from a restriction in food supplies. Probably both $k$ and $L_{\infty}$ would change as a result of metabolic adaptations and compensatory feeding activity referred to above. Sutherland (1970) found evidence that density affected both the asymptotic size and the growth constant of Acmaea scabra. Griffiths (1981), studying populations of Choromytilus meridionalis at different levels on the shore, found that both $L_{\infty}$ and $k$ were different at each level although at the 2 upper levels at one site the $k$ values were very similar and the major difference observed was in the value of $L_{\infty}$.

$L_{\infty}$ values have been calculated for the population in each experimental plot based on a single increment in length from the initial seeding to the final measurement at each plot. The overall value of the growth constant obtained from the data from all culture sites $(k=1.01)$ has been used in this computation.

The mean biomass ( $g$ dry wt tissue $\mathrm{m}^{-2}$ ) in each of the density plots over the period of the study was also calculated. Mean dry tissue weights were calculated using the expression

$\mathrm{D} / \mathrm{W}=5.05 \times 10^{-3} . \mathrm{W}+4.15 \times 10^{-2}$

(Broom, 1982)

Estimates of numerical density on each sampling date (from Broom, 1980) were then combined with the estimates of mean weight to give an estimate of mean biomass for each sampling date. These separate estimates were then summed for each plot and divided by the number of estimates to give a value of average biomass for each plot over the sampling period. The relationship between calculated $L_{\infty}$ and average biomass is presented in Fig. 8a, and that between $\mathrm{L}_{\infty}$ and exposure in Fig. 8 b. No attempt was made to take into account the effects of biomass changes in the exposure plots because the low initial densities and the mortality experienced in each plot during the course of the study resulted in limited changes in biomass.

From Fig. 8a there is a clear increase in $L_{\infty}$ with decreasing density that follows a straight line relation-
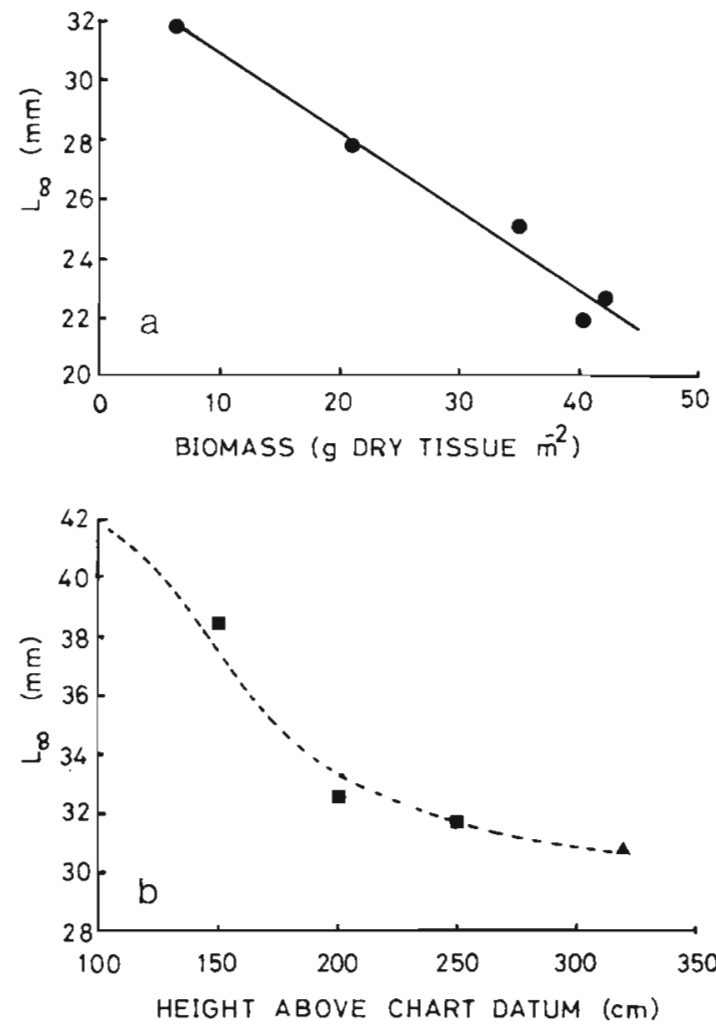

Fig. 8. Anadara granosa. Derived estimates of $L_{\infty}$ against mean biomass (a) and height above chart datum (b) for experimental populations at Site 4, Kuala Selangor. In (b) a a are estimates from experimental populations but $\boldsymbol{\Delta}$ is an estimate of $L_{\infty}$ of a sub-population at Site 1, Kuala Selangor, $320 \mathrm{~cm}$ above $\mathrm{CD}$ (1977 yr class) derived from data presented in Fig. 4. Curve in (b) is fitted by eye 
ship: $L_{\infty}=33.6( \pm 0.77)-0.266( \pm 0.0239) B$ where $B=$ biomass ( $\mathrm{g}$ dry tissue $\left.\mathrm{m}^{-2}\right) ; L_{\infty}$ is expressed in $\mathrm{mm}$, and values of one standard error are given in parentheses. The regression explains a significant amount of the variation $\left(F_{1,3}=124, \mathrm{p} \ll 0.01\right)$. The predicted $L_{\infty}$ at zero biomass is low compared with that computed for the artificial culture sites. This could be because (1) the populations at the latter sites occupied elevations betweeen 75 and $200 \mathrm{~cm}$ above chart datum whereas those in the density plots were sown at $250 \mathrm{~cm}$ above chart datum, and (2) the site used for the experimental plots was one not normally used for culture operations and it may have been a less productive area.

Fig. $8 \mathrm{~b}$ consists of only 3 points derived from the experimental plots but also included is an eye-estimate of the likely $L_{\infty}$ value of the sub-population at Site $1,320 \mathrm{~cm}$ above chart datum (derived from an eyeestimate of the $W_{\infty}$ value) in an attempt to provide an insight into the likely form of the relationship between $L_{\infty}$ and elevation.

A tentative sigmoid curve has been drawn through these points on the basis of the following assumptions. Firstly, decreasing elevations would not increase the animal's feeding time once it is below the intertidal zone and in any case genotypic limitations on maximum size would probably come into play somewhat before then. Secondly, at higher shore levels compensatory feeding or metabolic activity would be likely to help maintain growth in the face of increasing exposure but there is probably also a level above which growth rate declines rapidly with increasing exposure unless preceded by the death of the organism due to the increasing effects of other factors such as thermal stress.

Studies providing some support for the existence of such a relationship include that of Wolff and de Wolf (1977) who, working in intertidal soft substrata, found a positive sigmoid curve relating biomass of molluscs to immersion time. However, below low water level the relationship broke down. Wolff and de Wolf do not state whether changes in biomass were due to changes in numbers, mean weight or a combination of both. Spencer et al. (1978), working with Crassostrea gigas, found evidence of a sigmoid relationship between growth rate and exposure at low elevations (0 to $30 \%$ exposure), and the data presented by Griffiths (1981) for Choromytilus meridionalis is consistent with the hypothesis that $L_{\infty}$ will vary with exposure in a sigmoid fashion.

The development of Equation 3 is a first step towards standardisation of a relationship between density (in terms of biomass per unit area) and $L_{\infty}$. In conjunction with the weight/length relationships this could be used in a yield function to take account of the effects of changing biomass upon growth rates. Unfortunately it is not possible, at this stage, to arrive at a similar relationship for height above chart datum vs. $L_{\infty}$ because the actual form of the relationship is still uncertain and because insufficient data are available. The confirmation of the form of this curve should be the next task for those concerned with Anadara granosa culture operations.

Acknowledgements. I would like to record my gratitude to the following, who provided considerable physical assistance with field work during this study: Mr. Lee Thian Heng, Mr. Kwong Kee Siong and Miss Lee Yoke Shum.

This work was financed partly by the University of Malaya (Grant F 118/78) and partly by a grant from the Division of Marine Sciences, UNESCO, administered by the University of Malaya.

\section{LITERATURE CITED}

AnselI, A. D., Parulekar, A. H. (1978). On the rate of growth of Nuculana minuta (Müller) (Bivalvia: Nuculanidae). J. Mollusc. Stud. 44: 71-82

Bayne, B. L., Worral, C. M. (1980). Growth and production of mussels Mytilus edulis from two populations. Mar. Ecol. Prog. Ser. 3: 317-328

Beukema, J. J., Cadee, G. C., Jansen, J. J. M. (1977). Variability of the growth rate of Macoma balthica (L.) in the Wadden Sea in relation to availability of food. In: Keegan, B. F., O'Ceidigh, P., Boaden, P. S. (eds.) Biology of benthic organisms. Pergamon, Oxford, pp. 69-77

Broom, M. J. (1980). Community and production ecology of Anadara granosa (L.) with particular reference to its gastropod predators. Ph. D. thesis, University of Malaya, Kuala Lumpur

Broom, M. J. (1982). Size-selection, consumption rates and growth of the gastropods Natica maculosa (Lamarck) and Thais carinifera (Lamarck) preying on the bivalve Anddara granosa (L.). J. exp. mar. Biol. Ecol. 56: 213-233

Broom, M. J. (In press). Structure and seasonality in a Malaysian mudflat community. Estuar. coast. Shelf Sci.

Calow, P. (1977). Ecology, evolution and energetics: a study in metabolic adaptation. Adv. Ecol. Res. 10: 1-62

Crisp, D. J. (1971). Energy flow measurements. In: Holme, N. A., McIntyre, A. D. (eds.) Methods for the study of marine benthos. IBP Handbook No. 16. Blackwell Scientific, Oxford. pp. 197-323

Government of Malaysia (1980). Annual fisheries statistics, 1979, Dept. of Fisheries, Kuala Lumpur, Malaysia

Green, R. H. (1973). Growth and mortality in an arctic intertidal population of Macoma balthica (Pelecypoda, Tellinidae). J. Fish. Res. Bd Can. 30: 1345-1348

Green, R. H., Hobson, K. D. (1970). Spatial and temporal structure in a temperate intertidal community, with special emphasis on Germma gemma (Pelecypoda, Mollusca). Ecology 51: 999-1011

Griffiths, R. J. (1981). Population dynamics and growth of the bivalve Choromytilus meridionalis (Kr.) at different tidal levels. Estuar. coast. Shelf Sci. 12: 101-118

Gulland, J. A. (1969). Manual of methods for fish stock assessment, Pt. I. Fish population analysis. FAO manuals in fisheries science No. 4. FAO, Rome

Gulland, J. A. (1972). Population dynamies of world fisheries, University of Washington Press, Seattle 
Moore, P. G. (1977). Inorganic particulate suspensions in the sea and their effects on marine animals. Oceanogr. Mar. Biol. A. Rev. 15: 225-363

Pathansali, D. (1963a). The larva of the cockle Anadara granosa Linn. Bull. Singapore Natl. Mus. 32: 163-164

Pathansali, D. (1963b). On the effect of salinity changes on the activity of the cockle, A. granosa L. Malayan Agric. J. 44: $18-25$

Pathansali, D. (1966). Notes on the biology of the cockle, Anadara granosa L. Proc. Indo-Pacific Fish. Counc. 11: $84-98$

Pathansali, D., Soong, M. K. (1958). Some aspects of cockle (Anadara granosa L.) culture in Malaya. Proc. Indo-Pacific Fish Counc. 8: 26-31

Ricker, W. E. (1975). Computation and interpretation of biological statistics of fish populations. Bull. Fish. Res. Bd Can. 191: 1-382

Scottish Marine Biological Association (1973). Annual report of the Council S. M. B. A., OBAN

Spencer, B. E., Key, D., Millican, P. F., Thomas, M. J. (1978). The effect of intertidal exposure on the growth and survival of hatchery-reared Pacific oysters /Crassostrea gigas
Thunberg) kept in trays during their first ongrowing season. Aquaculture 13: 191-204

Strickland, J. D. H., Parsons, T R. (1968). A practical handbook of seawater analysis. Bull. Fish. Res. Bd Can. 167: $1-311$

Sutherland, J. P. (1970). Dynamics of high and low populations of the limpet Acmaea scabra (Gould). Ecol. Monogr 40: $169-188$

Winter, J. E. (1978). A review on the knowledge of suspension-feeding in lamellibranchiate bivalves, with special reference to artificial aquaculture system. Aquaculture 13: $1-34$

Wolff, W. J., de Wolf, L. (1977). Biomass and production of zoobenthos in the Grevelingen estuary, The Netherlands. Estuar, coast. Shelf Sci. 5: 1-24

Yamaguchi, M. (1975). Estimating growth parameters from growth rate data. Problems with marine sedentary invertebrates. Oecologia (Berl.) 20: 321-332

Yoo, S. K. (1971). Biological studies on the propagation of important bivalves. 3. Growth and morphological variations of the ark shell Anadara granosa bisenensis Schrenck et. Reinhart (In Korean). Publ. Mar. Lab. Pusan Fish. Coll. 4: 19-27

This paper was submitted to the editor; it was accepted for printing on April 7, 1982 